\title{
FGFR1OP wt Allele
}

National Cancer Institute

\section{Source}

National Cancer Institute. FGFR1OP wt Allele. NCI Thesaurus. Code C54460.

Human FGFR1OP wild-type allele is located within $6 \mathrm{q} 27$ and is approximately $41 \mathrm{~kb}$ in length. This allele, which encodes FGFR1 oncogene partner protein, plays a role in anchoring microtubules to the centrosome. Translocation of the FGFR10P gene is associated with certain myeloproliferative disorders. 